http://www.atbp.onaft.edu.ua/

kryptohrafycheskoy tekhnyky (po materyalam zarubezhnoy pechaty) // Zashchyta ynformatsyy. -

1994.-№1.-P.42-47.

[25] ChmoraA L. Krythhosystema s deponyrovanyem klyucha//Sop pes 1997. - №3 - P.34-39.

[26] HOST R 34.10 - 94. Ynformatsyonnaya tekhnopohyya. Kryptohrafycheskaya zashchyta ynformatsyy Protsedury vyrabotky y proverky èlektronnoy tsyfrovoy podpysy na baze asymmetrychnoho kryptohrafycheskoho alhorytma.

УДК 66.012:66.048.3

\title{
МАТЕМАТИЧНЕ МОДЕЛЮВАННЯ ДИНАМІЧНИХ РЕЖИМІВ ПРОЦЕСУ РЕКТИФІКАЦЇ̈ ПРИ ЗАСТОСУВАННІ РУХЛИВИХ КЕРУЮЧИХ ВПЛИВІВ
}

\section{Шейкус А. Р.}

Український державний хіміко-технологічний університет, Дніпро, Україна

ORCID: https://orcid.org/0000-0002-5575-098X

E-mail: a.sheykus@gmail.com

Copyright $(\subset) 2018$ by author and the journal "Automation of technological and business - processes.

This work is licensed under the Creative Commons Attribution International License (CC BY).

http://creativecommons.org/licanses/by/4.0

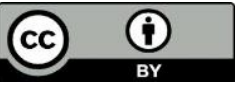

ONAFT

Open Access

DOI:

Анотація. Підвищення якості керування об'єктами з розподіленими параметрами, до яких відноситься процес ректифікації, можливо досягти використанням рухливих впливів. Відомо, щзо переміщення за висотою колони точки подання живлення або перерозподіл даного потоку між двома контактними пристроями апарату дозволяє забезпечити недосяжні традиційним керуванням техніко-економічні показники стаціонарних режимів. При иъвому перехідні процеси в колоні при використанні рухливих впливів залишалися недослідженими.

У статті розроблено математичну модель динаміки процесу ректифікації, щзо враховує рухливі керуючі впливи, а також досліджено особливості динамічних режимів роботи колони при їх використанні. В моделі передбачено можливість реалізачії різних за формами і інтенсивностями збурень $і$ керуючих впливів за декількома каналами одночасно або у визначені моменти часу. Модель дозволяє проводити розрахунки процесів багатокомпонентної $i$ складної ректифікаиії, може використовуватися при моделюванні пускових режимів.

Прочес ректифікації внаслідок використання рухливих впливів виходить зі стану динамічної рівноваги. Встановлено, щу новий стаціонарний режим досягається регулюванням тиску наверху колони, рівнів в ємностях для збору кубового залишку $i$ дистиляту. Запропоновано використання ПІД-регуляторів з впливами на витрати холодоагенту в конденсатор $і$ продуктів поділу. Динамічна модель прочесу доповнена описом даних контурів автоматичного регулювання.

3 використанням розробленої моделі проведено обчислювальні експерименти на прикладі колони для поділу суміші метанол-вода. Доведено, щзо перехідні процеси при використанні рухливих керуючих впливів на процес ректифікації характеризуються допустимими показниками якості.

Abstract. Improving the control quality of objects with distributed parameters, including the rectification process, could be achieved by using mobile actions. It is known that moving along the column height of the feed supply point or redistributing a given flow between the apparatus' two contact devices allows getting the technical and economic indicators of stationary modes unattainable by using traditional control. Also, the transient responses in the column when using movable influences remained unstudied.

The article developed a mathematical model of the distillation process dynamics, considering mobile control actions, as well as there have been studied the dynamic modes' features of column operation when used them. The model allows implementing disturbances and control actions of various kinds and intensities via several channels simultaneously or at certain points of time. The model allows computing the processes of multicomponent and complex distillation, and can be used to compute the starting modes. 
http://www.atbp.onaft.edu.ua/

Due to mobile actions, the distillation process leaves the dynamic equilibrium state. It was established that a new stationary mode is achieved by regulating the pressure at the column top, the levels of the bottom product and distillate. There are proposed the PID controllers with effects on the refrigerant flow rate into the condenser and separation products. The process dynamic model is supplemented by a description of these automatic control loops.

By the developed model the computational experiments were carried out on the example of a column for separation of a methanol-water mixture. It is proved that transient responses are characterized by acceptable quality indicators when using mobile control actions on the distillation process.

Ключові слова: ректифікація, рухливе керування, модель динаміки, перехідний процес, тарілка живлення.

Keywords: distillation, control, mobile action, dynamic model, transient response, feed tray.

Вступ. Інтенсифікація виробництва, створення високоефективних апаратів великої потужності вимагають відповідного забезпечення сировинним матеріалом. Висока якість сировини і кінцевої продукції в хімічній, нафтохімічній, харчовій та багатьох інших галузях промисловості забезпечується використанням масообмінних процесів, серед яких особливе місце займає процес ректифікації.

Поділ рідинних сумішей на індивідуальні компоненти високої чистоти методами ректифікації здійснюється в спеціальних апаратах колонного типу, ширина яких може становити кілька метрів, висота - десятків метрів. Колони оснащені кількома десятками контактних пристроїв, на яких відбуваються процеси тепло- і масообміну між рідинною і паровою фазами [1].

Як об'єкт керування ректифікаційна колона характеризується високою енергоємністю і собівартістю продуктів, великим числом параметрів, їх взаємозв'язком, розподіленістю, значними запізнюваннями і інерційністю керуючих каналів [2]. Керування таким об'єктом необхідно здійснювати з урахуванням наведених особливостей і застосуванням інноваційних систем, так як традиційні методи не задовольняють високим вимогам, що висуваються до якості і собівартості одержуваних продуктів.

Для об'єктів з розподіленими параметрами успішно застосовують системи розподіленого [3], рухливого [4, 5] керування. Відомо, що можливість вибору закону руху матеріального або енергетичного джерела дозволяє здійснювати переведення розподіленого об'єкта в стани, що недосяжні в класі нерухливих керуючих впливів, підвищити якість і швидкодію існуючих систем керування. Розробка систем автоматичного рухливого керування процесами ректифікації є актуальною науковою задачею.

Аналіз літературних даних і постановка проблеми. Для чіткого поділу компонентів суміші необхідні колони 3 великим числом контактних пристроїв. Інерційність таких апаратів ускладнює експериментальне дослідження їх динамічних характеристик, які необхідні для вибору i розрахунку систем автоматизації. Вирішення задач оптимального управління і оптимізації процесів ректифікації неможливе без використання методів і результатів математичного моделювання.

В даний час широке застосування одержали програмні засоби моделювання хіміко-технологічних процесів, такі як Aspen Plus [6, 7], Aspen Dynamics [8, 9], ChemCAD [10] та інші. Дані системи мають зручний інтерфейс, великі бібліотеки та бази даних фізико-хімічних властивостей речовин, типових процесів і апаратів, модулі проектування, дослідницьких розрахунків, оптимізації та економічної оцінки технологічних схем. Разом 3 цим, їх використання викликає складнощі з причин великих витрат на придбання і підтримку, обмеження набору апаратів типовими і ідеалізованими моделями, неможливості одержання результатів, що не передбачені розробниками.

На сьогодні розроблено велику кількість математичних моделей процесу ректифікації [11 - 13]. Точний опис перехідних процесів в системах автоматичного керування приводить до систем складних нелінійних диференціальних рівнянь $з$ частинними похідними [14]. Для запобігання цього ставиться завдання статичної оптимізації процесу або спрощення моделювання обгрунтованими припущенями.

Ректифікаційну колону, яка є розподіленим об’єктом, можливо розглядати як систему, що складається 3 ланок із зосередженими параметрами і чистими запізнюваннями: тарілок, кип’ятильників, конденсаторів, секцій насадки. Кожен 3 цих елементів має певну розділову здатність відносно потоків, які надходять до нього. Для кожної ланки складається система звичайних диференціальних рівнянь для балансових залежностей і нелінійних рівнянь, що описують гідродинаміку, процеси тепло- і масообміну [15].

Традиційні керуючі впливи на процес ректифікації призначені безпосередньо для впливу на матеріальний i енергетичний баланси колони, в той час як рухливі передбачають зміни не інтенсивностей потоків, а просторової координати їх надходження в апарат. На практиці розподілене, рухливе керування зводиться до вибору тарілок живлення та відбору проміжних продуктів [16], перерозподілу сировини при ії двухпоточній подачі в колону.

У напрямі рухливого керування процесами ректифікації вирішено завдання розробки адаптованої статичної моделі колони [17], вибору методу вирішення [18] і оптимізації процесу [19]. Доведено, що використання рухливих керуючих впливів забезпечує недосяжні стаціонарні режими роботи установок, проте не дослідженими залишаються режими динамічні. 
Мета і завдання дослідження. Мета роботи - розробка математичної моделі динаміки процесу ректифікації, що враховує рухливі керуючі впливи, а також дослідження особливостей динамічних режимів роботи колони при їх використанні.

Завдання:

1. Розробка динамічної моделі процесу ректифікації, що дозволяє враховувати рухливі керуючі впливи, і алгоритму розрахунку нестаціонарних режимів роботи колони.

2. Вибір параметрів, що підлягають стабілізації при керуванні процесом, і моделювання відповідних контурів автоматичного регулювання.

3. Розрахунок і дослідження особливостей динамічних режимів роботи ректифікаційної колони при використанні рухливих керуючих впливів на процес.

Методи і матеріали досліджень. Процес ректифікації в результаті дії зовнішніх збурень виходить зі стану динамічної рівноваги. При цьому склади рідини і пари, їх витрати, ентальпії, а також температура і тиск на кожному контактному пристрої, в кубі колони і флегмовій ємності починають змінюватися.

Характерними особливостями такого технологічного об'єкта як ректифікаційна колона є багатовимірність, внутрішні взаємозв'язки між параметрами, їх розподіленість в просторі апарату і в часі, наявність значного числа збурень. Моделювання і розрахунок такого об’єкта необхідно здійснювати з урахуванням наведених його властивостей.

3 метою спрощення розрахунків і необхідності врахування при моделюванні безлічі параметрів, що впливають на процес і також змінюють свої величини в часі, в динамічної моделі ректифікаційної колони, що розробляється, прийняті наступні припущення:

1) рідина на тарілках перемішується миттєво; це дозволяє розглядати тарілку як об'єкт із зосередженими параметрами;

2) гідравлічне запізнювання потоків рідини і пари не враховується;

3) віддача тепла в навколишнє середовище відсутня;

4) рідина на контактних пристроях знаходиться за температури кипіння, пар - температури конденсації;

5) інерційні властивості колони визначаються утримуючою здатністю колони за рідиною;

6) часом встановлення гідродинамічних режимів і фазової рівноваги в колоні можливо знехтувати в порівнянні 3 часом встановлення концентрацій.

При моделюванні ректифікаційна колона розглядається як сукупність елементарних ланок, що еквівалентні одній тарілці, випарнику куба, конденсатору і збірку флегми верху колони.

На рис. 1 схематично відображено основні матеріальні і енергетичні (теплові) потоки, що надходять і відводяться 3 контактного пристрою колони.

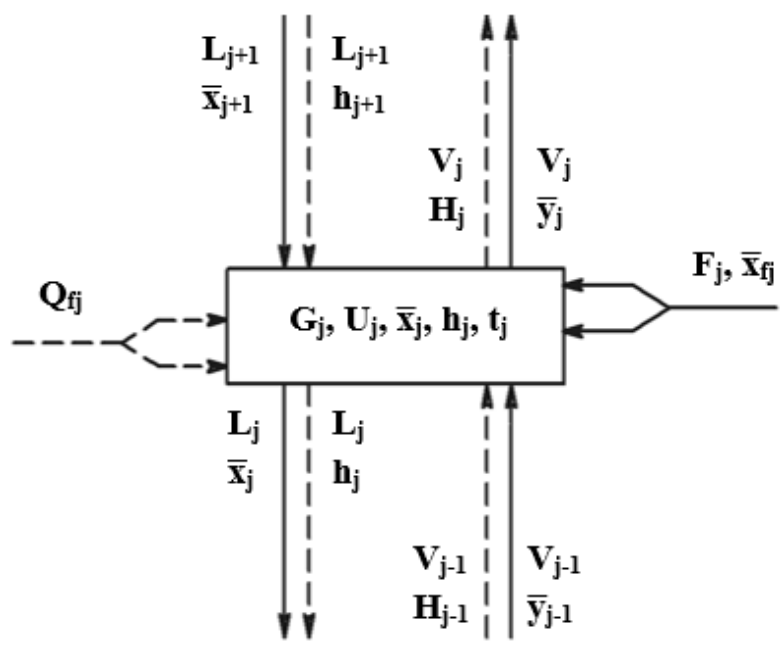

Рис. 1 - Схема матеріальних і енергетичних потоків контактного пристрою ректифікаційної колони

Перехідний процес розраховується послідовно, у визначених часових точках, які віддалені одна від одної на величину $\Delta \tau$

$$
\tau[k+1]=\tau[k]+\Delta \tau=(k+1) \cdot \Delta \tau
$$

де $\tau[0]=0, k$ - ціле число, $k=0,1, \ldots, m$.

Основні контрольовані збурення на процес наступні: витрата $F_{j}(\tau)$, склад $\bar{x}_{f j}(\tau)$, температура живлення $t_{f j}(\tau)$ i тиск в трубопроводі живлення $P_{f j}(\tau)$. 
В момент часу $\tau[k]$ відомі значення всіх показників контактного пристрою, що вказані на рис. 1 . Дані величини визначаються використанням моделі статики для початкового моменту часу $\tau[0]$ або безпосередньо моделюванням перехідних процесів.

Розрахунок колони проводиться в одному напрямку, від низу до верху, тому при переході до ј-ої тарілки вже відомі характеристики парового потоку, який залишає контактний пристрій, що розташовано нижче, в момент часу $\tau[k+1]: V_{j-1}[k+1], \bar{y}_{j-l}[k+1], H_{j-1}[k+1]$. Для рідинного потоку, що надходить на тарілку, необхідно використовувати в розрахунках його характеристики в момент часу $\tau[k]: L_{j+1}[k], \bar{x}_{j+1}[k], h_{j+1}[k]$.

Величинами, які розраховуються, $\epsilon$ витрати і характеристики потоків, що залишають тарілку, а також температура і кількість рідини на ній в наступний момент часу $\tau[k+1]: L_{j}[k+1], V_{j}[k+1], \bar{x}_{j}[k+1], \bar{y}_{j}[k+1], h_{j}[k+1], H_{j}[k+1], G_{j}[k+1]$, $t_{j}[k+1]$.

3 метою врахування рухливих керуючих впливів на процес в математичній моделі, що розробляється, кожний контактний пристрій розглядається як потенційна тарілка живлення

$$
\begin{cases}F_{j}=q \cdot F, & j=N_{f, 1}, \\ F_{j}=(1-q) \cdot F, & j=N_{f, 2}, \\ F_{j}=0, & j \neq N_{f, 1}, \neq N_{f, 2} .\end{cases}
$$

На кожну тарілку надходять рідина з контактного пристрою, що розташований вище, і пара $з$ нижчого. Залишають тарілку рідина, склад якої відповідає складу на даній тарілці, і пара, характеристики якої залежать від ефективності масообміну на контактному пристрої. Загальний матеріальний баланс контактного пристрою

$$
\frac{d G_{j}}{d \tau}=L_{j+1}+V_{j-1}+F_{j}-L_{j}-V_{j}
$$

Рівняння матеріальних балансів за компонентами

$$
\frac{d\left(G_{j} \cdot x_{j, i}\right)}{d \tau}=L_{j+1} \cdot x_{j+1, i}+V_{j-1} \cdot y_{j-1, i}+F_{j} \cdot x_{f, j, i}-L_{j} \cdot x_{j, i}-V_{j} \cdot y_{j, i} .
$$

Ліва частина (3)

$$
\frac{d\left(G_{j} \cdot x_{j, i}\right)}{d \tau}=G_{j} \cdot \frac{d x_{j, i}}{d \tau}+x_{j, i} \cdot \frac{d G_{j}}{d \tau} .
$$

Підстановка (4) i (2) в (3) дозволяє одержати рівняння для розрахунку концентрацій компонентів в рідинній фазі

$$
G_{j} \cdot \frac{d x_{j, i}}{d \tau}=L_{j+1} \cdot\left(x_{j+1, i}-x_{j, i}\right)+V_{j-1} \cdot\left(y_{j-1, i}-x_{j, i}\right)+V_{j} \cdot\left(x_{j, i}-y_{j, i}\right)+F_{j} \cdot\left(x_{f, j, i}-x_{j, i}\right) .
$$

Постійна часу контактного пристрою колони

$$
T_{j}=\frac{G_{j}}{L_{j+1}+V_{j-1}-V_{j}+F_{j}} .
$$

Рівняння теплового балансу аналогічне (5) з урахуванням того, що накопичення тепла пов'язане зі зміною ентальпії рідини, що знаходиться на тарілці, а втрати тепла в навколишнє середовище відсутні

$$
G_{j} \cdot \frac{d h_{j}}{d \tau}=L_{j+1} \cdot\left(h_{j+1}-h_{j}\right)+V_{j-1} \cdot\left(H_{j-1}-h_{j}\right)+V_{j} \cdot\left(h_{j}-H_{j}\right)+F_{j} \cdot\left(h_{f, j}-h_{j}\right) .
$$

Суттєвий вплив на зміну кількості речовини на контактному пристрої колони в динамічному режимі має конструктивне оформлення тарілки. Для тарілок ректифікаційної колони з переливом справедливо припущення про сталість рівня рідини. Утриманням парової фази рідинною можливо знехтувати, об’єм рідини на тарілці - величина постійна, а кількість речовини

$$
G=\frac{\pi \cdot d^{2} \cdot U \cdot \rho}{4 \cdot \mu}
$$

Густина рідинної суміші і іiі молярна маса визначаються відповідно до принципу адитивності і розрахунку парціальних густин і молярних мас. Залежність густини чистого $i$-ого компонента від температури $t$ лінійна

$$
\rho_{i}=\rho_{i, 1} \cdot t+\rho_{i, 2} \text {. }
$$

Густина суміші

$$
\rho=\frac{1}{\sum_{i=1}^{n}\left(\frac{x_{i}}{\rho_{i}}\right)}=\frac{1}{\sum_{i=1}^{n}\left(\frac{x_{i}}{\rho_{i, 1} \cdot t+\rho_{i, 2}}\right)} .
$$

Молярні маси -величини постійні для чистих речовин. Молярна маса суміші 


$$
\mu=\sum_{i=1}^{n}\left(\mu_{i} \cdot x_{i}\right) .
$$

3 урахуванням (10) і (11) кількість речовини на контактному пристрої

$$
G_{j}=\frac{\pi \cdot d_{j}^{2} \cdot U_{j}}{4 \cdot \sum_{i=1}^{n}\left(\mu_{i} \cdot x_{j, i}\right) \cdot \sum_{i=1}^{n}\left(\frac{x_{j, i}}{\rho_{i, 1} \cdot t_{j}+\rho_{i, 2}}\right)} .
$$

Кількість речовини - функція складу рідинної фази, що знаходиться на тарілці в момент часу, що розраховується. Рівні $U_{j} є$ коефіцієнтами налаштування динамічної моделі.

Склад парової фази розраховується згідно з припущенням 8) і сталістю коефіцієнтів масовіддачі в рідинній $\beta_{x, j}$ i паровій $\beta_{y, j}$ фазах

$$
\begin{gathered}
m_{j}=\frac{\partial y_{j}^{*}(\bar{x})}{\partial x_{j}}, \\
K_{y, j}=\frac{S}{\frac{1}{\beta_{y, j}}+\frac{m_{j}}{\beta_{x, j}}}, \\
\eta_{j}=1-e^{-\frac{K_{y, j}}{V_{j-1}}}, \\
y_{j, i}=y_{j-1, i}+\left(y_{j, i}^{*}-y_{j-1, i}\right) \cdot \eta_{j, i} .
\end{gathered}
$$

Рівноважний склад парової фази $\bar{y}_{j}^{*}$ визначається за моделлю фазової рівноваги [20] і у загальному вигляді може бути представлений як функція від складу рідинної фази і тиску на контактному пристрої

$$
\bar{y}_{j}^{*}=f\left(\bar{x}_{j}, P_{j}\right) .
$$

Одночасно з (17) ітераційними методами розраховується температура на контактному пристрої

$$
t_{j}=f\left(\bar{x}_{j}, P_{j}\right)
$$

3 урахуванням (18) ентальпії рідинної і парової фаз $є$ функціями їх складів і тисків на тарілці

$$
\begin{gathered}
h_{j}=f\left(\bar{x}_{j}, P_{j}\right), \\
H_{j}=f\left(\bar{y}_{j}, P_{j}\right) .
\end{gathered}
$$

Живлення може подаватися в колону у вигляді переохолодженої рідини, киплячої рідини, парорідинної суміші, пари, що конденсується, або перегрітої пари. Фазовий стан визначає ентальпію потоку сировини [21]

$$
h_{f, j}=f\left(\bar{x}_{f, j}, P_{f, j}, t_{f, j}\right) .
$$

Залежності (1) - (21) дозволяють вирішити завдання розрахунку динамічних режимів окремого контактної пристрою колони. Пропонується наступний алгоритм визначення шуканих величин.

1) Перевіряється умова подачі потоку живлення на тарілку, що моделюється. У разі виконання умови розраховуються ентальпія сировини $h_{f, j}[k+1]$ (21) і витрата тепла в колону.

2) Визначаються концентрації рідинної фази на контактному пристрої (5)

$$
\begin{aligned}
& x_{j, i}[k+1]=x_{j, i}[k]+ \\
& +\Delta \tau \cdot \frac{L_{j+1}[k] \cdot\left(x_{j+1, i}[k]-x_{j, i}[k]\right)+V_{j-1}[k] \cdot\left(y_{j-1, i}[k]-x_{j, i}[k]\right)}{G_{j}[k]}+ \\
& +\Delta \tau \cdot \frac{V_{j}[k] \cdot\left(x_{j, i}[k]-y_{j, i}[k]\right)+F_{j}[k] \cdot\left(x_{f, j, i}[k]-x_{j, i}[k]\right)}{G_{j}[k]} .
\end{aligned}
$$

3) Склад і тиск на контактному пристрої дозволяють визначити ентальпію рідинної фази $h_{j}[k+1](19)$. 
4) Проводяться розрахунки рівноважних фазових умов (17), температури $t_{j}[k+1](18)$, ККД контактного пристрою у випадку бінарної ректифікації (13) - (15) і складу парової фази $\bar{y}_{j}[k+1]$ (18), що залишає тарілку.

5) Склад парової фази визначає ентальпію $H_{j}[k+1](20)$.

6) Розраховуються молярні маси (11) і густини (10) рідинної суміші з використанням $\bar{x}_{j}[k], t_{j}[k]$ и $\bar{x}_{j}[k+1], t_{j}[k+1]$.

7) Визначається кількість речовини на контактному пристрої згідно з умовою сталості рівня рідини на тарілці

$$
\begin{gathered}
\Delta U_{j}=U_{j}[k+1]-U_{j}[k]=\frac{4}{\pi \cdot d_{j}^{2}} \cdot\left(\frac{G_{j}[k+1] \cdot \mu_{j}[k+1]}{\rho_{j}[k+1]}-\frac{G_{j}[k] \cdot \mu_{j}[k]}{\rho_{j}[k]}\right)=0 ; \\
G_{j}[k+1]=G_{j}[k] \cdot \frac{\mu_{j}[k] \cdot \rho_{j}[k+1]}{\mu_{j}[k+1] \cdot \rho_{j}[k]} .
\end{gathered}
$$

8) Витрата парової фази, що залишає контактний пристрій, розраховується за тепловим балансом (7)

$$
\begin{aligned}
& V_{j}[k+1]=L_{j+1}[k] \cdot \frac{h_{j+1}[k]-h_{j}[k]}{H_{j}[k]-h_{j}[k]}+V_{j-1}[k] \cdot \frac{H_{j-1}[k]-h_{j}[k]}{H_{j}[k]-h_{j}[k]}+ \\
& +F_{j} \cdot \frac{h_{f j}[k]-h_{j}[k]}{H_{j}[k]-h_{j}[k]}-G_{j}[k] \cdot \frac{h_{j}[k+1]-h_{j}[k]}{\Delta \tau \cdot\left(H_{j}[k]-h_{j}[k]\right)} .
\end{aligned}
$$

9) Рівняння загального матеріального балансу контактного пристрою (2) дозволяє визначити останню невідому величину - витрату рідинної фази, що залишає тарілку

$$
L_{j}[k+1]=L_{j+1}[k]+V_{j-1}[k]+F_{j}[k]-V_{j}[k]-\frac{G_{j}[k+1]-G_{j}[k]}{\Delta \tau} .
$$

Або з врахуванням (22)

$$
L_{j}[k+1]=L_{j+1}[k]+V_{j-1}[k]+F_{j}[k]-V_{j}[k]-\frac{G_{j}[k] \cdot\left(\frac{\mu_{j}[k] \cdot \rho_{j}[k+1]}{\mu_{j}[k+1] \cdot \rho_{j}[k]}-1\right)}{\Delta \tau} .
$$

При розрахунку ректифікаційної колони дані операції здійснюють для всіх контактних пристроїв послідовно від низу апарату. Далі величина $k$ збільшується на 1 і всі розрахунки повторюють для наступного моменту часу.

При розрахунках випарника колони величинами, що визначаються, є витрати і характеристики потоків, які залишають куб, а також температура, кількість рідини і рівень в ємності в наступний момент часу $\tau[k+1]: W[k+1]$, $V_{0}[k+1], \bar{x}_{0}[k+1], \bar{y}_{0}[k+1], h_{0}[k+1], H_{0}[k+1], G_{0}[k+1], U_{0}[k+1], t_{0}[k+1]$.

При розрахунках дефлегматора: витрати і характеристики потоків, що залишають флегмову ємність, витрата холодоагенту в конденсатор, а також кількість речовини і рівень в збірнику флегми в момент часу $\tau[k+1]: F l[k+1]$, $D[k+1], \bar{x}_{d}[k+1], \bar{x}_{f l}[k+1], t_{f l}[k+1], h_{d}[k+1], h_{f l}[k+1], F_{m 3}[k+1], G_{d}[k+1], U_{d}[k+1]$.

Складання системи рівнянь, яка описує випарник куба колони і дефлегматор, за аналогією до моделі контактного пристрою (2) - (21) не становить особливих труднощів і в даній роботі опускається.

Очевидно, що перехідні процеси в ректифікаційної колоні підпорядковуються законам збереження матерії і енергії. Зміна величини будь-якого параметра процесу приводить до переходу колони зі стаціонарного в динамічний режим роботи, а забезпечення нового стаціонарного режиму неможливе без цілеспрямованих впливів на матеріальні та енергетичні потоки апарату.

Таким чином, при керуванні процесом ректифікації одночасно з рухливими обов'язковими є і традиційні керуючі впливи. Точки застосування останніх знаходяться на кінцях колони, а моделі динаміки куба і дефлегматора необхідно доповнити моделями необхідних контурів регулювання параметрів процесу.

Найважливіші традиційні керуючі впливи на процес полягають в змінах витрат тепла в кубі і зрошування, що подається в колону. Дані дії визначають навантаження апарату за рідинною і паровою фазами, продуктивність і собівартість продукції, що одержується. Розрахунок оптимальних величин даних впливів реалізується 3 використанням прогнозуючої нелінійної математичної моделі статики за алгоритмами статичної оптимізації процесу ректифікації [19]. 
3 метою підтримки матеріального балансу низу колони необхідно стабілізувати рівень в кубовій ємності шляхом зміни витрати кубового залишку. Передавальна функція за керуючим каналом $U_{w}-W$ відповідає інтегрувальній ланці

$$
W_{o}(s)=-\frac{1}{T_{w, o} \cdot s},
$$

3 постійною часу

$$
T_{w, o}=\frac{\pi \cdot d_{w}^{2} \cdot \rho_{0}}{4 \cdot \mu_{0}}
$$

Знак «мінус» у (24) вказує зворотну залежність між рівнем в ємності і витратою кубового продукту. Коефіцієнт передавальної функції не є постійним, так як молярна маса і густина кубового продукту залежать від його складу i температури.

Розузгодження

$$
\Delta U_{0}[k+1]=U_{0}[k+1]-U_{0, z} .
$$

При використанні ПІД-регулятора складові керуючого впливу

$$
\begin{gathered}
u_{p}[k+1]=K_{p} \cdot \Delta U_{0}[k+1], \\
u_{i}[k+1]=u_{i}[k]+K_{p} \cdot \frac{\Delta \tau}{T_{i}} \cdot \Delta U_{0}[k+1], \\
u_{d}[k+1]=K_{p} \cdot \frac{T_{d}}{\Delta \tau} \cdot\left(\Delta U_{0}[k+1]-\Delta U_{0}[k]\right) .
\end{gathered}
$$

Нове значення витрати кубового продукту з урахуванням негативного зворотного зв'язку і від'ємності передавальної функції (24)

$$
W[k+1]=W[k]+u_{p}[k+1]+u_{i}[k+1]+u_{d}[k+1] .
$$

Регулювання рівня в збірнику флегми $U_{d}$ здійснюється шляхом відведення необхідної кількості дистиляту $D$. Постійна часу інтегрувальної ланки, якою описується флегмова ємність

$$
T_{d, o}=\frac{\pi \cdot d_{d}^{2} \cdot \rho_{d}}{4 \cdot \mu_{d}} .
$$

Регулювання тиску наверху колони реалізується шляхом зміни витрати холодоагенту $F_{m 3}$ в конденсатор. При цьому збільшується витрата тепла $Q_{d}$, яке відводиться від пароподібного продукту верху колони, конденсується більше пари, що знижує тиск в апараті.

Надлишковий тиск у колоні пов'язаний з накопиченням парової фази в міжтарілочному просторі ректифікаційної колони. Постійна часу

$$
T_{P, o}=\frac{(N+1) \cdot S \cdot h_{y} \cdot\left(H_{N}-h_{d}\right)}{R \cdot T_{N} \cdot \Delta h_{m 3}} .
$$

Температура $T_{N}$ в (30) розраховується як температура конденсації парової фази, склад якої $\bar{y}_{N}$, при тиску $P_{N}$.

Для регулювання рівня дистиляту і тиску наверху колони також застосовують ПІД-регулятори. Розрахунки $D(\tau)$ i $F_{m 3}(\tau)$ здійснюють відповідно до (25) - (29).

3 урахуванням витрат холодоагенту $F_{m 3}$ швидкість конденсації пари

$$
V_{N, \text { cond }}[k+1]=G_{d}[k] \cdot \frac{h_{d}[k+1]-h_{d}[k]}{\Delta \tau \cdot\left(H_{N}[k]-h_{d}[k]\right)}+F_{m 3}[k] \cdot \frac{h_{m 3}[k]-h_{m 4}[k]}{H_{N}[k]-h_{d}[k]} .
$$

Залежності (23) для останньої тарілки колони і (31) для дефлегматора дозволяють визначити зміну кількості речовини в кожній міжтарілочній ємності колони

$$
\Delta G_{y, j}[k+1]=\frac{V_{N}[k]-V_{N, c o n d}[k]}{N+1} \cdot \Delta \tau
$$

Тиск на кожному контактному пристрої в момент часу, що розраховується 

http://www.atbp.onaft.edu.ua/

$$
P_{j}[k+1]=P_{j}[k]+\frac{\Delta G_{y, j}[k+1] \cdot R \cdot T_{j}[k+1]}{S \cdot h_{y}} .
$$

Розроблена модель динаміки дозволяє досліджувати перехідні процеси в колоні при застосуванні рухливих керуючих впливів.

Досліджено колону для поділу бінарної суміші метанол-вода, що містить 18 контактних пристроїв, виносні кип’ятильник і дефлегматор. Концентрація метанолу в живленні становить 0,273 мол. частки. Показники, що визначають регламентований режим роботи колони: $N_{f}=9, Q_{w}=6,4$ ГДж/год, $D=62,8$ кмоль/год, $F=229,3$ кмоль/год, $P_{f}=P_{j=0}=P_{j=18}=1$ атм, $\beta_{x}=3060,5$ кмоль $/\left(\mathrm{м}^{2} \cdot\right.$ год $), \beta_{y}=142,82$ кмоль $/\left(\mathrm{м}^{2} \cdot\right.$ год $)$, живлення, зрошування і дистилят знаходяться за температури кипіння. Цільовим компонентом є метанол, продуктом - дистилят. Початковий режим розраховано з використанням моделі статики.

Розрахунки проведено з кроком $\Delta \tau$, що складає 0,05 с. Використано наступні величини коефіцієнтів налаштування моделі: рівень в кубової ємності і збірнику флегми $U_{w}=U_{d}=0,3$ м; рівень на контактних пристроях $U_{j}=0,04$ м. Відстань між тарілками $h_{y}=0,2$ м.

Для стабілізації рівнів кубового продукту, дистиляту, а також тиску наверху колони використано ПІД-регулятори. Параметри їх налаштування наведено в таблиці 1.

Таблиця 1 - Параметри налаштування ПІД-регуляторів

\begin{tabular}{|c|c|c|c|}
\hline \multirow{2}{*}{ Величина, що регулюється } & \multicolumn{2}{|c|}{ Параметри } \\
\cline { 2 - 3 } & $K_{p}$ & $T_{i}, \mathrm{c}$ & $T_{d}, \mathrm{c}$ \\
\hline Рівень в кубовій ємності $U_{w}$ & 0,683 & & 68,22 \\
\hline Рівень в збірнику флегми $U_{d}$ & 0,308 & \multirow{2}{*}{64,62} & \\
\hline Тиск наверху колони $P_{N}$ & 0,018 & & \\
\hline
\end{tabular}

\section{Результати досліджень.}

Досліджено перехідні процеси при використанні дискретних рухливих керуючих впливів, які полягають у зміні точки введення живлення в колону (рис. 2 -4). Переключення здійснювалось на сусідні з регламентованим контактні пристрої.

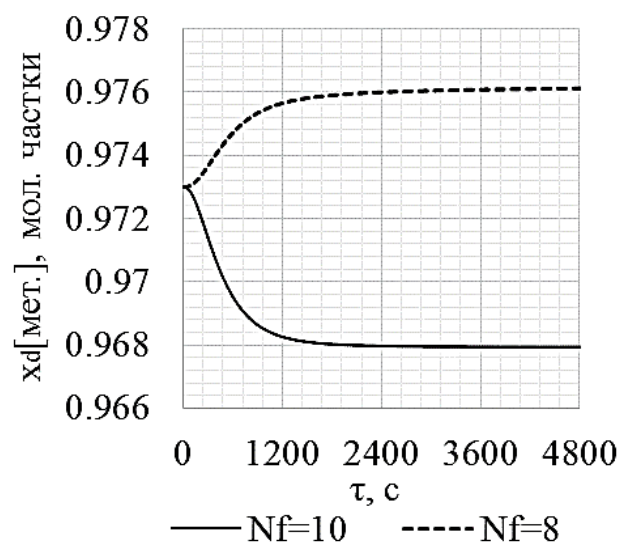

a)

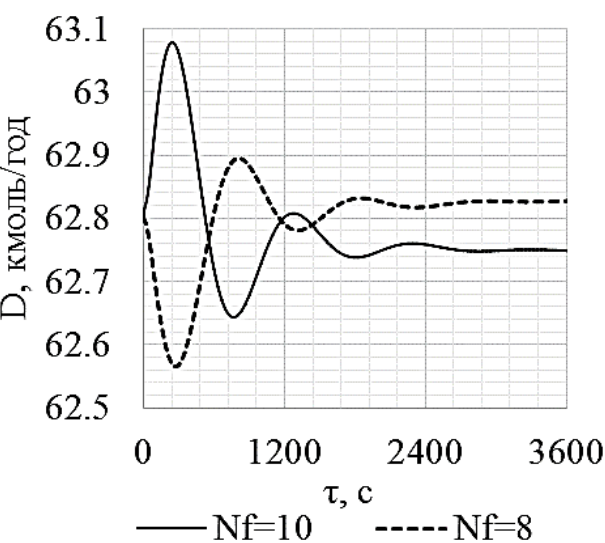

б)

Рис. 2 - Перехідні процеси за каналами «концентрація метанолу в дистиляті - номер тарілки живлення» (а) і «витрата дистиляту - номер тарілки живлення» (б) при зміні номера тарілки живлення 


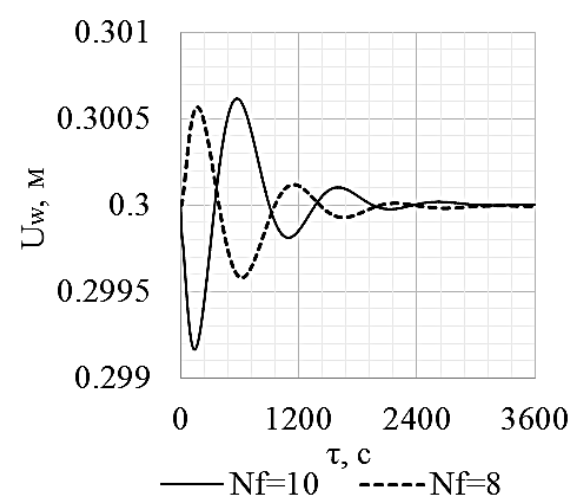

a)

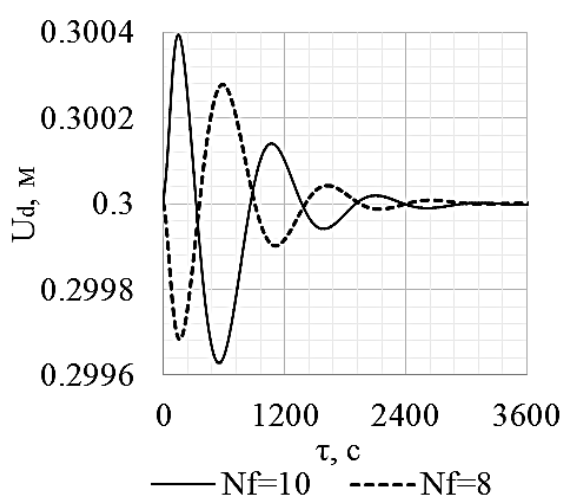

б)

Рис. 3 - Перехідні процеси за каналами «рівень в кубової смності - номер тарілки живлення» (а) i «рівень в збірнику флегми - номер тарілки живлення» (б) при зміні номера тарілки живлення

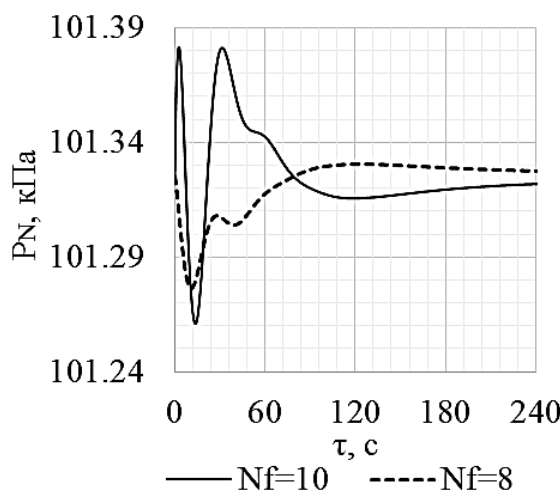

a)

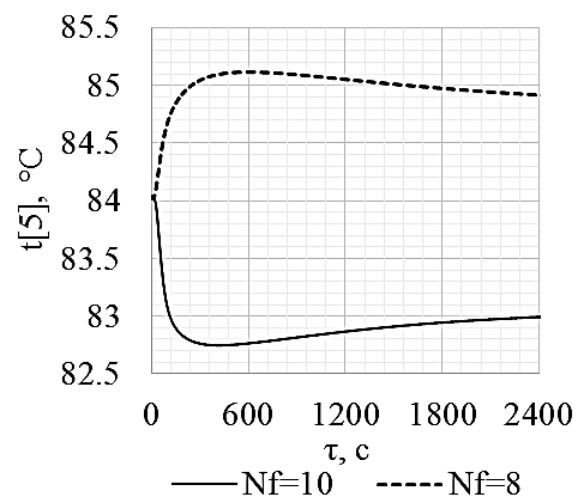

б)

Рис. 4 - Перехідні процеси за каналами «тиск наверху колони - номер тарілки живлення» (а) і «температура на контрольній тарілці - номер тарілки живлення» (б) при зміні номера тарілки живлення

Досліджено перехідні процеси при застосуванні неперервних рухливих керуючих впливів, які полягають у перерозподілі потоку живлення між двома контактними пристроями колони (рис. 5 - 7). В якості контактних пристроїв, між якими перерозподіляється живлення, обрано 7-у і 9-у тарілки колони.

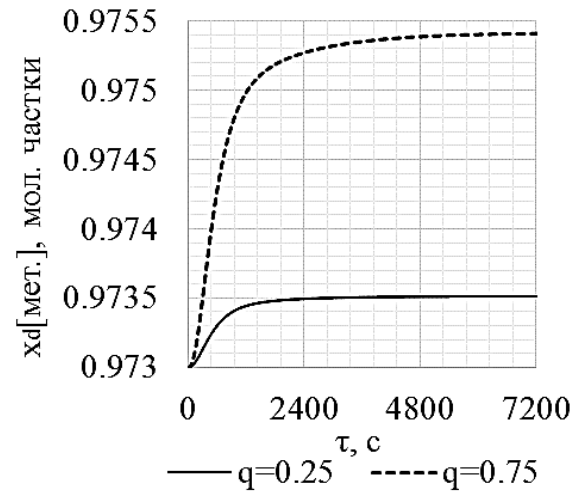

a)

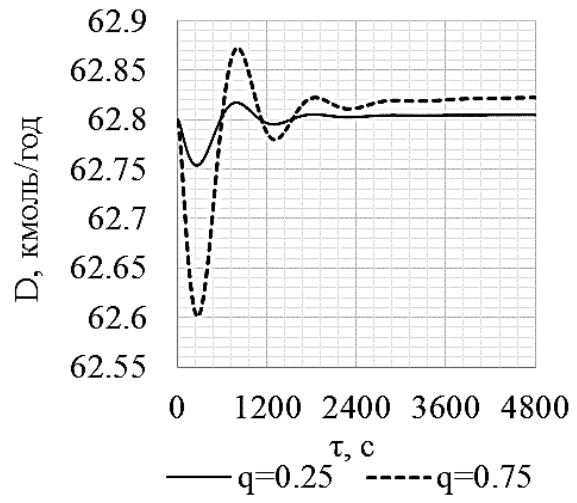

б)

Рис. 5 - Перехідні процеси за каналами «концентрація метанолу в дистиляті - коефіціснт перерозподілу живлення» (а) i «витрата дистиляту - коефіціснт перерозподілу живлення» (б) при зміні коефіціснта перерозподілу живлення 

http://www.atbp.onaft.edu.ua/

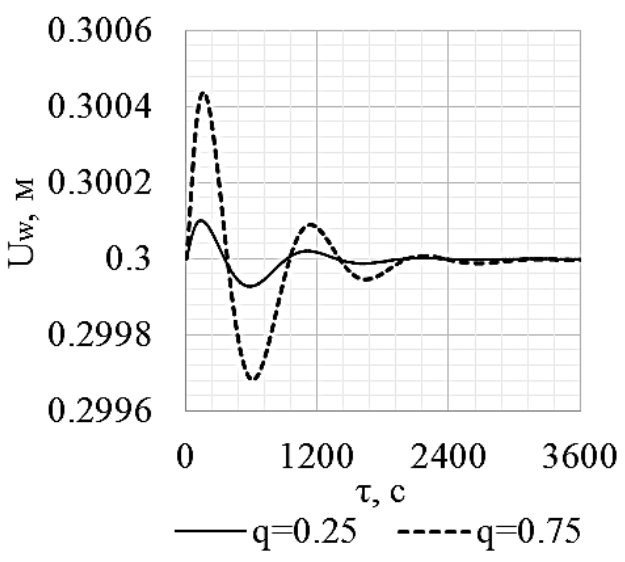

a)

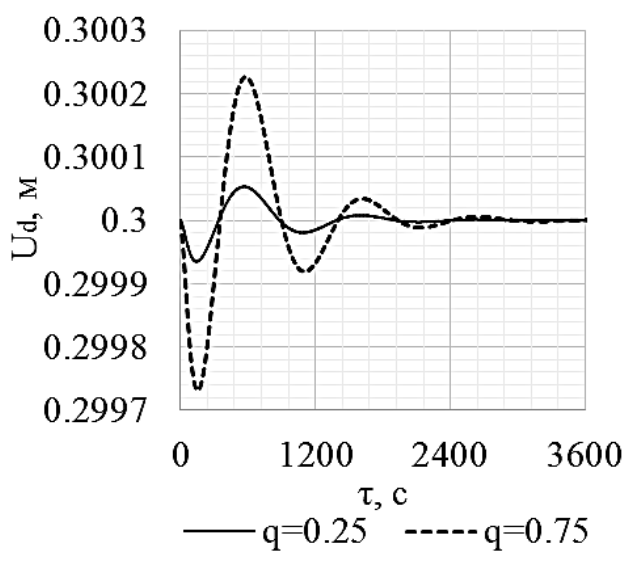

б)

Рис. 6 - Перехідні процеси за каналами «рівень в кубової смності - коефіцієнт перерозподілу живлення» (а) і «рівень в збірнику флегми - коефіцієнт перерозподілу живлення» (б) при зміні коефіціснта перерозподілу живлення

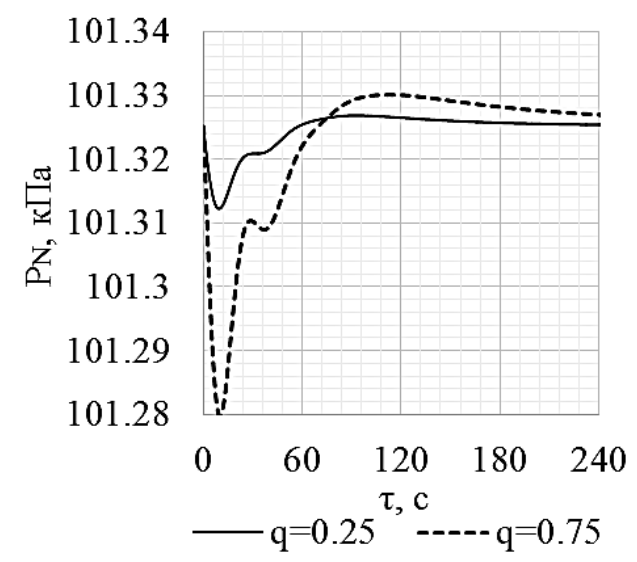

a)

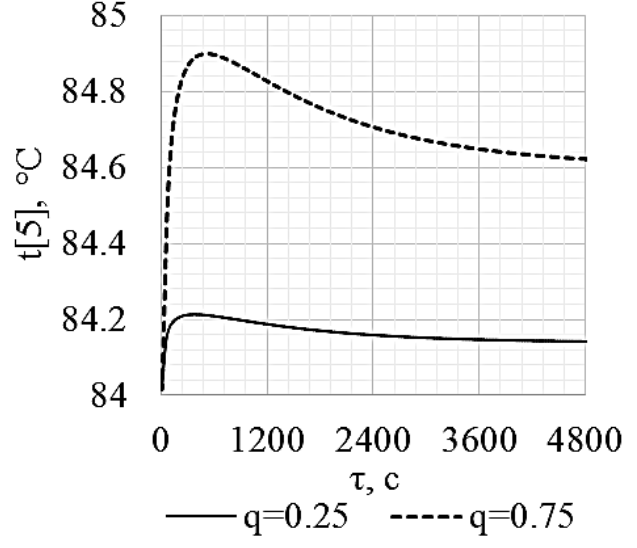

б)

Рис. 7 - Перехідні процеси за каналами «тиск наверху колони - коефіціснт перерозподілу живлення» (а) і «температура на контрольній тарілці - коефіцієнт перерозподілу живлення» (б) при зміні коефіцієнта перерозподілу живлення

\section{Обговорення результатів.}

Подання живлення на 8-у тарілку підвищує якість цільового продукту (рис. 2), що пояснюється наближенням до оптимальної точки введення живлення в колону за даним критерієм. Перехідні процеси за каналом $x_{d, n z}-N_{f}$ носять монотонний аперіодичний характер. Зміни концентрацій на інших контактних пристроях можуть характеризуватися перерегулюванням.

Зниження тарілки живлення приводить до підвищення рівня в кубовій ємності і зниження - у флегмовій (рис. 3). При регулюванні рівнів ПІД-регулятор змінює витрати кубового продукту і дистиляту. При переключенні подання живлення на 8-у тарілку вихід дистиляту починає знижуватися, але саме такий вплив по завершенні перехідного процесу дозволяє підвищити продуктивність колони.

Зниження якості і продуктивності при переключенні подання живлення на 10-у тарілку значніше, ніж підвищення - при поданні на 8-у.

Так як рухливі впливи не змінюють загальне матеріальне і енергетичне навантаження колони, то динамічні похибки при регулюванні рівнів незначні. Час регулювання становить одну годину і співставний з часом встановлення концентрацій і температур.

В якості контрольного обрано 5-й контактний пристрій колони (рис. 4). Підвищення концентрації метанолу в дистиляті при переключенні живлення на 8-у тарілку знижує його кількість в вичерпній частині апарату. Це приводить до підвищення концентрації важкого компонента і, як наслідок, температури на контрольній тарілці. 
Час регулювання тиску наверху колони незначний (рис. 4), що пояснюється меншим ємнісним запізнюванням за паровою фазою в порівнянні з рідинною і малою величиною постійної часу (30). Динамічні похибки, що пов’язані зі змінами енергетичного навантаження колони і витратою парової фази, несуттєві.

Характер перехідних процесів при підвищенні величини коефіцієнта перерозподілу аналогічний характеру при зниженні тарілки живлення, при цьому динамічні похибки і час регулювання залежать від значення $q$. Істотні зміни величини коефіцієнта перерозподілу приводять до збільшення тривалості перехідних процесів в колоні, а також викликають суттєву реакцію з боку показників процесу.

\section{Висновки.}

Використанням розробленої моделі динаміки процесу ректифікації досягається висока швидкість розрахунків нестаціонарних режимів. Можливе моделювання різних за формами і інтенсивностями збурень і керуючих впливів на процес за декількома каналами одночасно або в певні моменти часу.

Запропонований алгоритм розрахунку нестаціонарних режимів процесу ректифікації і структура моделі передбачають можливості врахування транспортних запізнювань парової і рідинної фаз в колоні, нестаціонарності процесів масо- і теплопередачі.

Рухливі керуючі впливи полягають у зміні не інтенсивностей матеріальних і енергетичних потоків, а просторової координати їх надходження в апарат. Цим пояснюються встановлені особливості перехідних процесів при автоматичному керуванні процесами ректифікації з використанням рухливих впливів.

Використання рухливих впливів не приводить до істотних динамічних похибок при керуванні ректифікаційною колоною. Час регулювання можливо порівняти з тривалістю перехідних процесів при основних збуреннях на процес.

У той же час, застосування лише рухливих впливів на процес ректифікації недостатньо. Для забезпечення нового оптимального стаціонарного режиму необхідні традиційні впливи на витрати продуктів поділу, зрошування, а також теплоносія і холодоагенту у випарник і конденсатор.

Модель дозволяє вести розрахунки процесів багатокомпонентної і складної ректифікації, може використовуватись для розрахунків пускових режимів колон. Результати проведених досліджень можуть застосовуватись при побудові систем автоматичного рухливого керування процесами ректифікації, систем адаптивного, оптимального керування 3 використанням прогнозуючих моделей.

\section{Умовні позначення.}

$D$ - мольна витрата дистиляту, кмоль/год;

$d$ - діаметр, м;

$F$ - мольна витрата живлення, кмоль/год;

$F l$ - мольна витрата зрошування, кмоль/год;

$G$ - кількість речовини, кмоль;

$H$ - ентальпія парової фази, кДж/кмоль;

$h$ - ентальпія рідинної фази, кДж/кмоль;

$h_{y}$ - відстань між тарілками, м;

$j$ - номер контактного пристрою;

$K$ - коефіцієнт масопередічі; коефіцієнт посилення;

$k$ - номер точки, що розраховується, перехідного процесу;

$L$ - мольна витрата рідинної фази, кмоль/год;

$m$ - тангенс кута нахилу дотичної до кривої рівноваги;

$N$ - кількість контактних пристроїв в колоні;

$n$ - кількість компонентів в суміші;

$N_{f}$ - номер тарілки живлення, величина дискретного рухливого керуючого впливу;

$P$ - тиск, МПа;

$Q$ - витрата тепла, кДж/год;

$q$ - коефіцієнт перерозподілу живлення, величина неперервного рухливого керуючого впливу, кмоль/кмоль;

$R$ - універсальна газова стала, кДж/(кмоль $\cdot \mathrm{K})$;

$S$ - ефективна площа тарілки, м $^{2}$;

$s$ - оператор передавальної функції;

$T$ - стала часу, с; температура, К;

$t$ - температура, ${ }^{\circ} \mathrm{C}$;

$U$ - рівень, м;

$u$ - керуючий вплив, кмоль/год;

$V$ - мольна витрата парової фази, кмоль/год; об'єм, м³ ;

$W$ - мольна витрата кубового продукту, кмоль/год;

$x$ - мольна концентрація компонента в рідинній фазі, кмоль/кмоль; 
$y$ - мольна концентрація компонента в паровій фазі, кмоль/кмоль.

Грецькі символи:

$\beta$ - коефіцієнт масовіддачі, який розраховано на одиницю ефективної площі тарілки, кмоль/(м²·год);

$\eta$ - ефективність масопереносу на контактному пристрої за Мерфрі;

$\mu$ - молярна маса, кг/кмоль;

$\rho-$ густина, кг $/ \mathrm{m}^{3}$;

$\tau-$ час, с.

Нижні індекси:

cond - параметр конденсату;

$d$ - параметр дистиляту, диференціювальна складова;

$f$ - параметр живлення;

$f l$ - параметр зрошування;

$i$ - параметр компонента суміші; інтегрувальна складова;

$j$ - параметр контактного пристрою колони;

$m 3$ - параметр холодоагенту, що надходить в дефлегматор;

$m 4$ - параметр холодоагенту, що відводиться $з$ дефлегматора;

$N$ - параметр верху колони;

$n z$ - параметр цільового компонента суміші;

$o$ - параметр об'єкта керування;

$P$ - параметр регулювання тиску;

$p$ - пропорційна складова;

w, 0 - параметр кубового продукту; параметр випарника куба колони;

$x$ - параметр рідинної фази;

$y$ - параметр парової фази;

$z$ - завдання.

Верхній індекс:

* - рівноважний параметр.

\section{Список використаних джерел}

[1] Sinnott R. Chemical Engineering Design / R. Sinnott, G. Towler. - Elsevier Butterworth-Heinemann, $2009 .-1038$ p.

[2] Mehta B.R. Industrial Process Automation Systems: Design and Implementation / B.R. Mehta, Y.J. Reddy. Butterworth-Heinemann, 2015. - 668 p.

[3] Werle L.O. Control Strategy with Distributed Action for Minimization of Transients in Distillation Column / L.O. Werle, C. Marangoni, J.G. Teleken, C. Sayer, R.F. Machado // Computer Aided Chemical Engineering. - 2009. - 27. P. 1527-1532. DOI: 10.1016/s1570-7946(09)70645-5

[4] Бутковский А.Г. Теория подвижного управления системами с распределенными параметрами / А.Г. Бутковский, Л.М. Пустыльников. - М.: Наука, 1980. - 384 с.

[5] Kubyshkin V.A. Mobile control of vibrations in systems with distributed parameters / V.A. Kubyshkin // Automation and Remote Control. - 2011. - 72 (10). - P. 2112-2122. DOI: 10.1134/S0005117911100109

[6] Cao Y. Comparison of pressure-swing distillation and extractive distillation with varied-diameter column in economics and dynamic control / Y. Cao, J. Hu, H. Jia, G. Bu, Z. Zhu, Y. Wang // Journal of Process Control. - 2017. - 49. - P. 925. DOI: $10.1016 /$ j.jprocont.2016.11.005

[7] Taqvi S.A. Optimization and Dynamics of Distillation Column Using Aspen Plus / S.A. Taqvi, L.D. Tufa, S. Muhadizir // Procedia Engineering. - 2016. - 148. - P. 978-984. doi:10.1016/j.proeng.2016.06.484

[8] Ma K. Control of an energy-saving side-stream extractive distillation process with different disturbance conditions / K. Ma, M. Yu, Y. Dai, Y. Ma, J. Gao, P. Cui, Y. Wang // Separation and Purification Technology. - 2019. - 210. - P. 195208. DOI: 10.1016/j.seppur.2018.08.004

[9] Luyben W.L. Aspen Dynamics simulation of a middle-vessel batch distillation process / W.L. Luyben // Journal of Process Control. - 2015. - 33. - P. 49-59. DOI: 10.1016/j.jprocont.2015.06.002

[10] Wang X.G. Simulation of Reactive Distillation Process with ChemCAD Software / X.G. Wang, Y.Y. Yang // Advanced Materials Research. - 2011. - 347-353. - P. 3706-3709. doi:10.4028/www.scientific.net/amr.347-353.3706

[11] Torgashov A. Comparative Study of Multicomponent Distillation Static Estimators Based on Industrial and Rigorous Model Datasets / A. Torgashov, S. Skogestad, A. Kozlov // IFAC-PapersOnLine. - 2016. - 49 (7). - P. $1187-1192$. DOI: 10.1016/j.ifacol.2016.07.369

[12] Ермолаева В.А. Математическое моделирование ректификации многокомпонентной смеси / В.А. Ермолаева, Д.М. Николаева, Н.Г. Столетовых // Международный журнал гуманитарных и естественных наук. - 2019. - 2-2. - С. 35-39. DOI: $10.24411 / 2500-1000-2019-10567$ 
http://www.atbp.onaft.edu.ua/

[13] Ramesh K. Nonlinear Model Predictive Control of a Distillation Column Using NARX Model / K. Ramesh, S.R.A. Shukor, N. Aziz // Computer Aided Chemical Engineering. - 2009. - 27. - P. 1575-1580. DOI: 10.1016/s15707946(09)70653-4

[14] Девятов Б.Н. Динамика распределенных процессов в технологических аппаратах, распределенный контроль и управление / Б.Н. Девятов, Н.Д. Демиденко, В.А. Охорзин - Красноярск: Красноярское книжное издательство, 1976. $-310 \mathrm{c}$.

[15] Кафаров В.В. Основы массопередачи / В.В. Кафаров. - 3-е изд. - М.: Высш. школа, 1979. - 439 с.

[16] Demidenko N.D. Distributed control for systems with distributed parametres / N.D. Demidenko, L.V. Kulagina // J. Sib. Fed. Univ. Eng. technol. - 2018. - 11 (2). - P. 221-228. DOI: 10.17516/1999-494X-0025

[17] Шейкус А.Р. Моделювання процесу багатокомпонентної ректифікації з врахуванням рухливих керуючих впливів / А.Р. Шейкус, В.Я. Тришкін, І.Л. Левчук // Комп'ютерне моделювання: аналіз, управління, оптимізація. - 2018. - № 1 (3). - C. 82-91.

[18] Sheikus A. Developing a technique for improving the efficiency of iterative methods for the calculation of the multicomponent rectification process / A. Sheikus, E. Belobrova, Ya. Dovgopoliy, I. Levchuk, V. Korsun // EasternEuropean Journal of Enterprise Technologies. - 2016. - Vol. 6, N 2 (84). - P. 38-44. - DOI: 10.15587/17294061.2016.85372

[19] Sheikus A.R. Static optimization of rectification processes using mobile control actions / A.R. Sheikus, V.Ya. Trishkin // Radio Electronics, Computer Science, Control. - 2018. - 1. - P. 192-201. DOI: 10.15588/1607-3274-2018$1-22$

[20] Шейкус А.Р. Моделирование парожидкостного равновесия при подвижном управлении процессами ректификации / А.Р. Шейкус, И.Л. Левчук, В.Я. Тришкин, В.И. Корсун // Вестник НТУ "ХПИ". Серия: Информатика и моделирование. - Харьков: НТУ "ХПИ". - 2016. - № 44 (1216). - С. 87-100. - DOI: 10.20998/2411-0558.2016.44.08

[21] Шейкус А.Р. Управление процессом ректификации с использованием подвижных управляющих воздействий с двумя степенями свободы [Текст] / А.Р. Шейкус, И.Л. Левчук, В.Я. Тришкин // Интегрированные технологии и энергосбережение. - 2017. - №1. - С. 60 - 72 .

\section{References}

[1] Sinnott, R., Towler, G. Chemical Engineering Design. Elsevier Butterworth-Heinemann, 1038 p., 2009.

[2] Mehta, B.R., Reddy, Y.J. Industrial Process Automation Systems: Design and Implementation. ButterworthHeinemann, 668 p., 2015.

[3] Werle, L.O., Marangoni, C., Teleken, J.G., Sayer, C., Machado, R.F. Control Strategy with Distributed Action for Minimization of Transients in Distillation Column. Computer Aided Chemical Engineering, 27, P. 1527-1532, 2009. https://doi.org/10.1016/S1570-7946(09)70645-5

[4] Butkovskij, A.G. Teorija podvizhnogo upravlenija sistemami s raspredelennymi parametrami. Moskva, Nauka, 384 s., 1980.

[5] Kubyshkin, V.A. Mobile control of vibrations in systems with distributed parameters. Automation and Remote Control, 72 (10), P. 2112-2122, 2011. https://doi.org/10.1134/S0005117911100109

[6] Cao, Y., Hu, J., Jia, H., Bu, G., Zhu, Z., Wang, Y. Comparison of pressure-swing distillation and extractive distillation with varied-diameter column in economics and dynamic control. Journal of Process Control, 49, P. 9-25, 2017. https://doi.org/10.1016/j.jprocont.2016.11.005

[7] Taqvi, S.A., Tufa, L.D., Muhadizir, S. Optimization and Dynamics of Distillation Column Using Aspen Plus. Procedia Engineering, 148, P. 978-984, 2016. https://doi.org/10.1016/j.proeng.2016.06.484

[8] Ma, K., Yu, M., Dai, Y., Ma, Y., Gao, J., Cui, P., Wang, Y. Control of an energy-saving side-stream extractive distillation process with different disturbance conditions. Separation and Purification Technology, 210, P. 195-208, 2019. https://doi.org/10.1016/j.seppur.2018.08.004

[9] Luyben, W.L. Aspen Dynamics simulation of a middle-vessel batch distillation process. Journal of Process Control, 33, P. 49-59, 2015. https://doi.org/10.1016/j.jprocont.2015.06.002

[10] Wang, X.G., Yang, Y.Y. Simulation of Reactive Distillation Process with ChemCAD Software. Advanced Materials Research, 347-353, P. 3706-3709, 2011. https://doi.org/10.4028/www.scientific.net/AMR.347-353.3706

[11] Torgashov, A., Skogestad, S., Kozlov, A. Comparative Study of Multicomponent Distillation Static Estimators Based on Industrial and Rigorous Model Datasets. IFAC-PapersOnLine, 49(7), P. 1187-1192, 2016. https://doi.org/10.1016/j.ifacol.2016.07.369

[12] Ermolaeva, V.A., Nikolaeva, D.M., Stoletovyh, N.G. Matematicheskoe modelirovanie rektifikacii mnogokomponentnoj smesi. Mezhdunarodnyj zhurnal gumanitarnyh i estestvennyh nauk, 2-2, S. 35-39, 2019. DOI: 10.24411/2500-1000-2019-10567

[13] Ramesh, K., Shukor, S.R.A., Aziz, N. Nonlinear Model Predictive Control of a Distillation Column Using NARX Model. Computer Aided Chemical Engineering, 27, P. 1575-1580, 2009. https://doi.org/10.1016/S15707946(09)70653-4

[14] Devjatov, B.N., Demidenko, N.D., Ohorzin, V.A. Dinamika raspredelennyh processov v tehnologicheskih apparatah, raspredelennyj kontrol' i upravlenie. Krasnojarsk, Krasnojarskoe knizhnoe izdatel'stvo, 310 s., 1976. 
http://www.atbp.onaft.edu.ua/

[15] Kafarov, V.V. Osnovy massoperedachi. Moskva, Vysshaja shkola, 439 s., 1979.

[16] Demidenko, N.D., Kulagina, L.V. Distributed control for systems with distributed parametres. J. Sib. Fed. Univ. Eng. technol, 11 (2), P. 221-228, 2018. https://doi.org/10.17516/1999-494X-0025

[17] Sheikus, A.R., Tryshkin, V.Ja., Levchuk, I.L. Modeljuvannja procesu bagatokomponentnoi' rektyfikacii' $z$ vrahuvannjam ruhlyvyh kerujuchyh vplyviv. Komp'juterne modeljuvannja: analiz, upravlinnja, optymizacija, 1(3), S. 82-91, 2018.

[18] Sheikus, A., Belobrova, E., Dovgopoliy, Ya., Levchuk, I., Korsun, V. Developing a technique for improving the efficiency of iterative methods for the calculation of the multicomponent rectification process. Eastern-European Journal of Enterprise Technologies, Vol. 6, N 2 (84), P. 38-44, 2016. https://doi.org/10.15587/1729-4061.2016.85372

[19] Sheikus, A.R., Trishkin, V.Ya. Static optimization of rectification processes using mobile control actions. Radio Electronics, Computer Science, Control, 1, P. 192-201, 2018. https://doi.org/10.15588/1607-3274-2018-1-22

[20] Sheikus, A.R., Levchuk, I.L., Trishkin, V.Ja., Korsun, V.I. Modelirovanie parozhidkostnogo ravnovesija pri podvizhnom upravlenii processami rektifikacii. Vestnik NTU "HPI". Serija: Informatika i modelirovanie, 44 (1216), S. 87-100, 2016. https://doi.org/10.20998/2411-0558.2016.44.08

[21] Sheikus, A.R., Levchuk, I.L., Trishkin, V.Ja. Upravlenie processom rektifikacii s ispol'zovaniem podvizhnyh upravljajushhih vozdejstvij s dvumja stepenjami svobody. Integrirovannye tehnologii i jenergosberezhenie, 1, S. 60-72, 2017.

УДК 697

\section{ДОСЛІДЖЕННЯ ПРОЦЕСІВ УТИЛІЗАЦІЇ ТЕПЛА ПАРОПОВІТРЯНИХ СУМІШЕЙ: ІМІТАЦЙНЕ МОДЕЛЮВАННЯ}

Ковальчук Д. А. ${ }^{1}$, Мазур О. В. ${ }^{2}$

Одеська національна академія харчових технологій, вул. Канатна, 112, Одеса, 65039, Україна

${ }^{1}$ асистент, ${ }^{2}$ доцент, к.т.н.

ORCID: ${ }^{1}$ 0000-0003-0549-5244, ${ }^{2}$ 0000-0001-7104-9010

E-mail: ${ }^{1}$ radiolomaster@gmail.com, ${ }^{2}$ mazur.av.ua@gmail.com

Copyright (C) 2018 by author and the journal "Automation of technological and business - processes. This work is licensed under the Creative Commons Attribution International License (CC BY). http://creativecommons.org/licanses/by/4.0

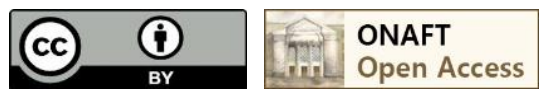

DOI:

\section{Анотація.}

Розглянуті основні підходи до розробки імітаційних моделей, освітлені їх недоліки та переваги. Розглянута імітаційна модель процесу глибокої утилізацї тепла пароповітряних сумішей з використанням парокомпресійного теплового насосу, до складу якої входять імітаційні моделі компресора, конденсатора, електронного розширювального вентиля, випарника, переохолоджувача та контактного теплообмінника - утилізатора тепла пароповітряних сумішей. Імітаиійні моделі ичих складових побудовані з використанням експериментальних даних, отриманих авторами в результаті виконання фізичних натурних експериментів на лабораторній дослідній установці. В імітаційній моделі випарника теплового насосу реалізовано функцію розрахунку «баластної» та «ефективної》 витрати холодоагенту. «Баластна» витрата виникає за рахунок переохолодження холодоагенту до температури кипіння $і$ супроводжується випаровуванням його частки, яка не приймає участі у відборі тепла випарником. Для ичього до імітаційної моделі випарника була додана підсистема розрахунку перепаду температур кипіння (тиску) по довжині випарника в залежності від витрати холодоагенту та температурного напору у випарнику, що враховує довжину ділянки випарника на якій відбувається кипіння рідкої фази. Залежність перепаду тиску по довжині випарника від витрат холодоагенту через нього є не монотонно зростаючою функцією а має екстремум і спадає при рівнях перегріва холодоагенту від 15 до $0{ }^{\circ} \mathrm{C}$. Тиск на виході випарника розраховується в 